\title{
Adaptation through chromosomal inversions in Anopheles
}

\author{
Diego Ayala ${ }^{1,2 *}$, Anna Ullastres ${ }^{3}$ and Josefa González ${ }^{3 *}$ \\ 1 UMR 224 MIVEGEC/BEES, IRD, Montpellier, France \\ 2 Unité d'Entomologie Médicale, Centre International de Recherches Médicales de Franceville, Franceville, Gabon \\ ${ }^{3}$ Comparative and Computational Genomics, Institute of Evolutionary Biology (CSIC-Universitat Pompeu Fabra), Barcelona, Spain
}

\author{
Edited by: \\ Frederic J. J. Chain, Max Planck \\ Institute for Evolutionary Biology, \\ Germany \\ Reviewed by: \\ Jacob A. Tennessen, Oregon State \\ University, USA \\ Mathieu Joron, Centre National de \\ la Recherche Scientifique, France \\ *Correspondence: \\ Diego Ayala, UMR 224 \\ MIVEGEC/BEES, IRD, 911 Ave., \\ Agropolis BP 64501, Montpellier \\ 34394, France \\ e-mail:diego.ayala@ird.fr; \\ Josefa González, Comparative and \\ Computational Genomics, Institute \\ of Evolutionary Biology \\ (CSIC-Universitat Pompeu Fabra), \\ Passeig Maritim de la Barceloneta \\ 37-49, 08003 Barcelona, Spain \\ e-mail: josefa.gonzalez@ \\ ibe.upf-csic.es
}

Chromosomal inversions have been repeatedly involved in local adaptation in a large number of animals and plants. The ecological and behavioral plasticity of Anopheles species-human malaria vectors-is mirrored by high amounts of polymorphic inversions. The adaptive significance of chromosomal inversions has been consistently attested by strong and significant correlations between their frequencies and a number of phenotypic traits. Here, we provide an extensive literature review of the different adaptive traits associated with chromosomal inversions in the genus Anopheles. Traits having important consequences for the success of present and future vector control measures, such as insecticide resistance and behavioral changes, are discussed.

Keywords: local adaptation, phenotypic traits, clinal patterns, insecticide resistance, behavioral traits

\section{INTRODUCTION}

The ecological success of a species depends on its ability to face the challenges of new biotic and abiotic scenarios. Evolutionary forces such as selection and migration shape the adaptive process (Lenormand, 2002), and the species' genome reflects this evolutionary process through modifications in its sequence and architecture. Among the most prominent adaptation mechanisms are chromosomal inversions (Dobzhansky, 1937; Krimbas and Powell, 1992; Hoffmann et al., 2004), which occur across a large number of taxa, including plants, mammals, fungi, and insects (Hoffmann and Rieseberg, 2008). Inversions join two evolutionary characteristics making them one of the most effective instruments for local adaptation: they involve several or even hundreds of genes, and recombination is drastically reduced in the heterozygote state (Stump et al., 2007; Kulathinal et al., 2009). Together, these characteristics produce a fertile scenario for the spread of genes involved in local adaptation in natural populations (Kirkpatrick and Barton, 2006; Feder and Nosil, 2009; Feder et al., 2011). Inversions can also affect fitness by influencing the expression and/or structure of genes located near their breakpoints (Pérez-Ortín et al., 2002; Puig et al., 2004; Calvete et al., 2012). Besides adaptation, inversions have also been implicated in speciation and sex chromosome evolution (Feder et al., 2003; van Doorn and Kirkpatrick, 2007; Hoffmann and Rieseberg, 2008). Historically, species of the genus Anopheles have received a great deal of attention in the study of chromosomal inversions.

Worldwide interest in the genus Anopheles stems from its inauspicious role in the transmission of malaria, responsible for over 1 million deaths per year (WHO, 2012). The success of Anopheles species in transmitting malaria parasites is closely related to its ecological capabilities. For instance, the ability of $A n$. gambiae to colonize a wide range of ecological settings across the whole of Africa has greatly contributed to making it the world's most proficient malaria vector (Figure 1) (White et al., 2011). Many Anopheles species have been extensively studied to better understand their biology, mainly with the aim of implementing vector control strategies. After the success and rapid spread of cytogenetic studies of Drosophila (Sturtevant and Dobzhansky, 1936; Krimbas and Powell, 1992), many other diptera species, among them Anopheles, were reexamined. Studies of the chromosome architecture in mosquitoes soon followed, as polytene chromosomes were readily accessible from different tissues, in particular nurse cells of half-gravid females and larvae salivary glands (Della Torre, 1997). Before long, natural populations of many important mosquito vectors were the subject of cytogenetic studies.

One of the most fertile fields of cytogenetic research in Anopheles is the study of inversions as speciation markers. Fixed inversions among taxonomically identical populations has led to the identification of species complexes (Green and Hunt, 1980; Subbarao et al., 1993; Ramírez and Dessen, 2000; Coluzzi et al., 2002). Moreover, deficits in heterozygotes and strong linkage disequilibrium among polymorphic rearrangements has provided evidence for the existence of reproductive isolation barriers and ongoing speciation processes (pre and post-zygotic) within species (Coluzzi, 1982; Costantini et al., 1999). Inversions have also been used as effective tools for phylogenetic analysis and chromosome evolution in the genus Anopheles. The study of 


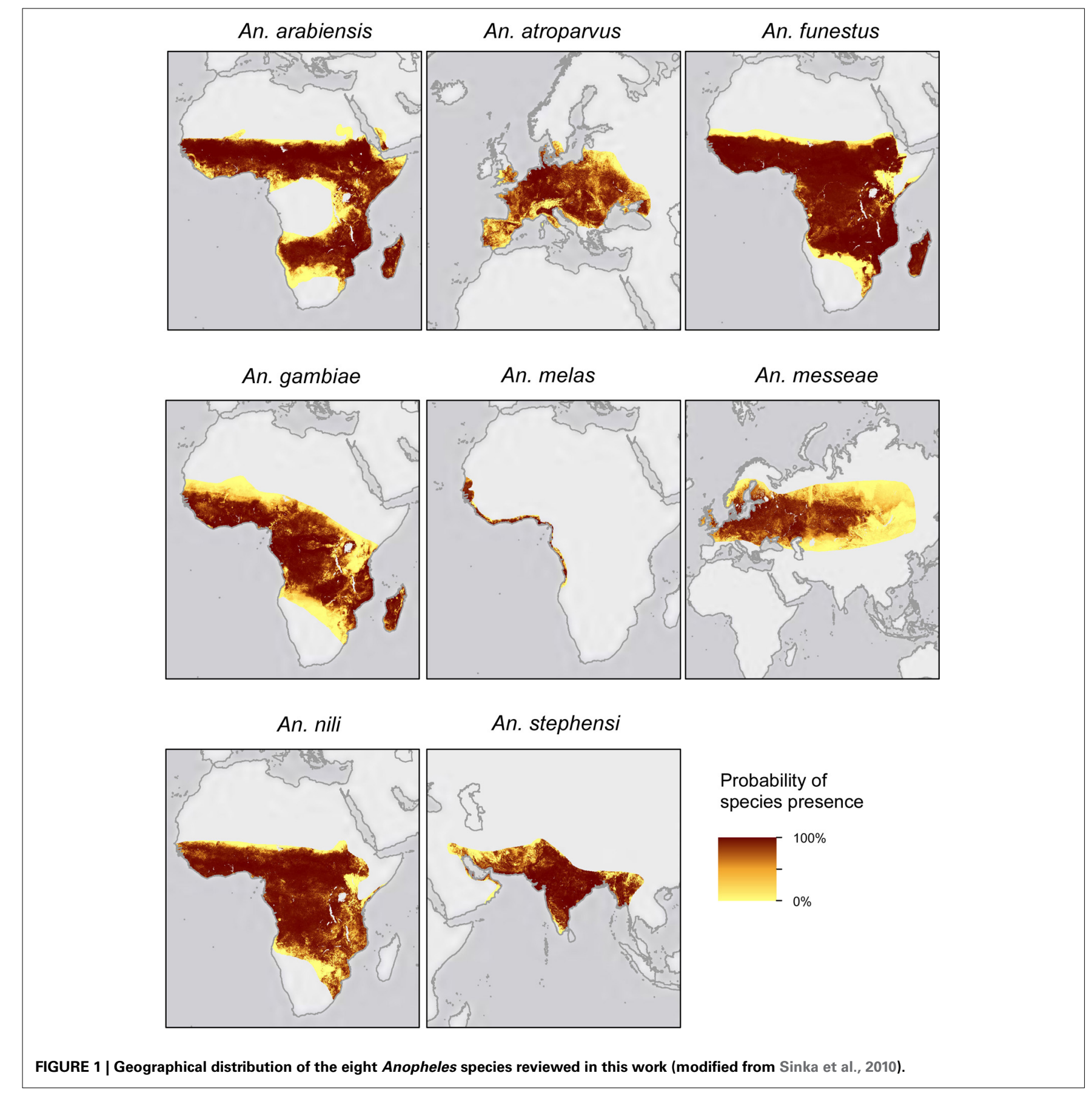

rearrangements across species has made it possible to infer the phylogenetic tree in the gambiae complex (e.g., Xia et al., 2008; Sharakhova et al., 2011). In addition, the study of breakpoint architecture has led to elucidation of the ancestry of species and inversions in them (Sharakhov et al., 2006; White et al., 2009). Lately, inversions have also been shown to be key factors in ecological success across distinct Anopheles species. A clear example is the acquisition by An. gambiae of inversions $2 L a$ and $2 R b$ introgressed from An. arabiensis (Della Torre et al., 1997; White et al., 2009). The ancestral range of An. gambiae was the rainforest and acquisition of these inversions from an arid species is thought to have given it the ecological and genetic flexibility to invade the savannas, which has most likely contributed to the establishment of this species as the foremost malaria vector (Coluzzi et al., 1979; Della Torre et al., 1997; Besansky et al., 2003; Ayala and Coluzzi, 2005). Environmental and/or geographical clines have also linked inversions to local adaption, corroborated in some species by seasonal changes in inversion frequencies (Simard et al., 2009; Ayala et al., 2011a). However, there have been few phenotypic experiments, i.e., experiments to validate the functional relationship between candidate genes and the specific trait in question, and genetic experiments due to limitations imposed by the difficulty 
of breeding most of the Anopheles species under insectary conditions. Recently, renewed interest in inversions has been fueled by the availability and relatively low cost of genome sequencing technologies. These promising new tools are aimed at deciphering the origin and evolution of inversions and ultimately the genes directly linked to the phenotypic trait associated with the chromosomal rearrangement (Kirkpatrick and Kern, 2012).

Through an exhaustive literature survey, we review here the evidence for the adaptive role of chromosomal inversions in the genus Anopheles. A total of eight species and 49 inversions have been associated with different phenotypic traits in Anopheles species in various studies (Figure 1, Table 1), the majority of them on the basis of associations between inversion frequencies and environmental/behavioral traits in natural populations. More recently, genomics and transcriptomics approaches and phenotypic assays in insectary conditions have substantially increased our understanding of the adaptive role of Anopheles inversions. To our knowledge, this is the first review providing a general overview of patterns, traits, and species with regard to the role of inversions in Anopheles local adaptation.

\section{ASSOCIATIONS BETWEEN INVERSIONS, TRAITS, AND FITNESS}

Inversions in Anopheles have been associated with several phenotypic traits, from insecticide resistance to behavioral characteristics and enzymatic activity (Table $\mathbf{1}$ ).

\section{INSECTICIDE RESISTANCE}

The first association studies linking chromosomal inversions with adaptation focused on the role of Anopheles atroparvus inversions in insecticide resistance (Figure 1) (D'Alessandro et al., 1957; Mosna et al., 1958). Since these initial studies, positive associations between inversions and different insecticides, both synthetic and natural, have been reported in three other species: An. arabiensis, An. gambiae, and An. stephensi (Figure 1, Table 1). Most research in this area is based on the study of inversion frequencies in artificially selected strains, although there are also some examples of associations between inversion frequencies and resistance in natural populations (Nigatu et al., 1995). Understanding the role of inversions in insecticide resistance could have direct implications for the success of malaria control programs by helping us understand the spread and introgression of resistance alleles between natural populations (Tripet et al., 2007; Enayati and Hemingway, 2010). One example of how inversions facilitate the spread of insecticide resistance alleles in mosquitos of the genus Culex is described by Labbé et al. (2007), who report that resistant alleles, which are highly deleterious when homozygous but adaptive when heterozygous, could potentially be kept in a heterozygous state through the presence of inversions.

\section{ENVIRONMENTAL ADAPTATION AND GEOGRAPHICAL DISTRIBUTION}

Frequency of chromosomal inversions has also been extensively associated with latitudinal, but less frequently with altitudinal, patterns in several Anopheles species (Table 1, Figure 1). In some cases, the particular environmental factor responsible for the association between the inversion and the clinal pattern has been identified (Touré et al., 1994; Petrarca et al., 2000). Polymorphic inversions non-randomly distributed both temporally and spatially have been reported in An. gambiae. More specifically, inversions are present at high frequencies or are fixed in xeric environments while they are virtually absent in mesic environments, and frequencies peak in dry seasons and trough in rainy seasons (Coluzzi et al., 1979). These patterns strongly suggest that inversions play a role in adaptation to xeric environments. Indeed, it has been shown that the presence of inversions can be predicted at $86 \%$ of the geographical sites studied on the basis of climatic variables, mean annual precipitation, evapotranspiration, minimum temperature, and maximum temperature having the greater explanatory power (Bayoh et al., 2001).

Several phenotypic experiments have been carried out to further characterize the selection agents responsible for spatial and temporal patterns of inversions in this malaria mosquito. Resistance to thermal and desiccation stresses were compared in carriers and non-carriers of inversion 2La (Gray et al., 2009; Rocca et al., 2009; Fouet et al., 2012) and inverted chromosomes were indeed found to exhibit greater resistance to both stresses, as expected on the basis of their association with arid environments. Gray et al. (2009) further established that resistance to desiccation was due to lower rates of water loss and higher initial body water content in flies carrying the inversion, while Fouet et al. (2012) found the inversion itself to play only a weak role in body size and also showed a possible involvement of the inversion $2 R b$ suggesting an epistatic effect of both inversions in desiccation resistance (Fouet et al., 2012).

\section{BEHAVIORAL TRAITS}

Aside from playing a role in insecticide resistance and the establishment and maintenance of clinal, altitudinal, and seasonal patterns, inversions have also been associated with behavioral characteristics such as indoor/outdoor resting and mate choice (Table 1).

Indoor resting behavior may be related to indoor environmental conditions as these generally display a higher nocturnal saturation deficit than the outdoor environment (Coluzzi et al., 1977). This hypothesis is supported in the cases of inversion $2 R a$ in $A n$. arabiensis and $2 L a$ in An. gambiae, as the first is negatively associated with humidity and the second has been repeatedly associated with arid climates in independent studies (Table 1). Some of these studies also found correlations between the same inversions and host preference, i.e., human vs. cattle (Bryan et al., 1987; Costantini et al., 1999). Resting behavior has implications for vector control programs because mosquitos that exhibit a preference for resting inside houses are easier targets for current vector control programs (bednet distribution or indoor insecticide spray).

Inversions have also been associated with mating behavior in An. funestus (Figure 1), where it has been reported that between $77 \%$ and $91 \%$ of matings are assortative based on karyotype (Ayala et al., 2012). Partner selection behavior has consequences for fitness since it may suppress offspring maladapted to local conditions, for example by preventing the reduction in fitness caused when different alleles adaptive to different environments are brought together in a hybrid individual. 


\section{Table 1 | Summary of traits, selection agents and evidence of selection available for 49 inversions described in eight different Anopheles} species.

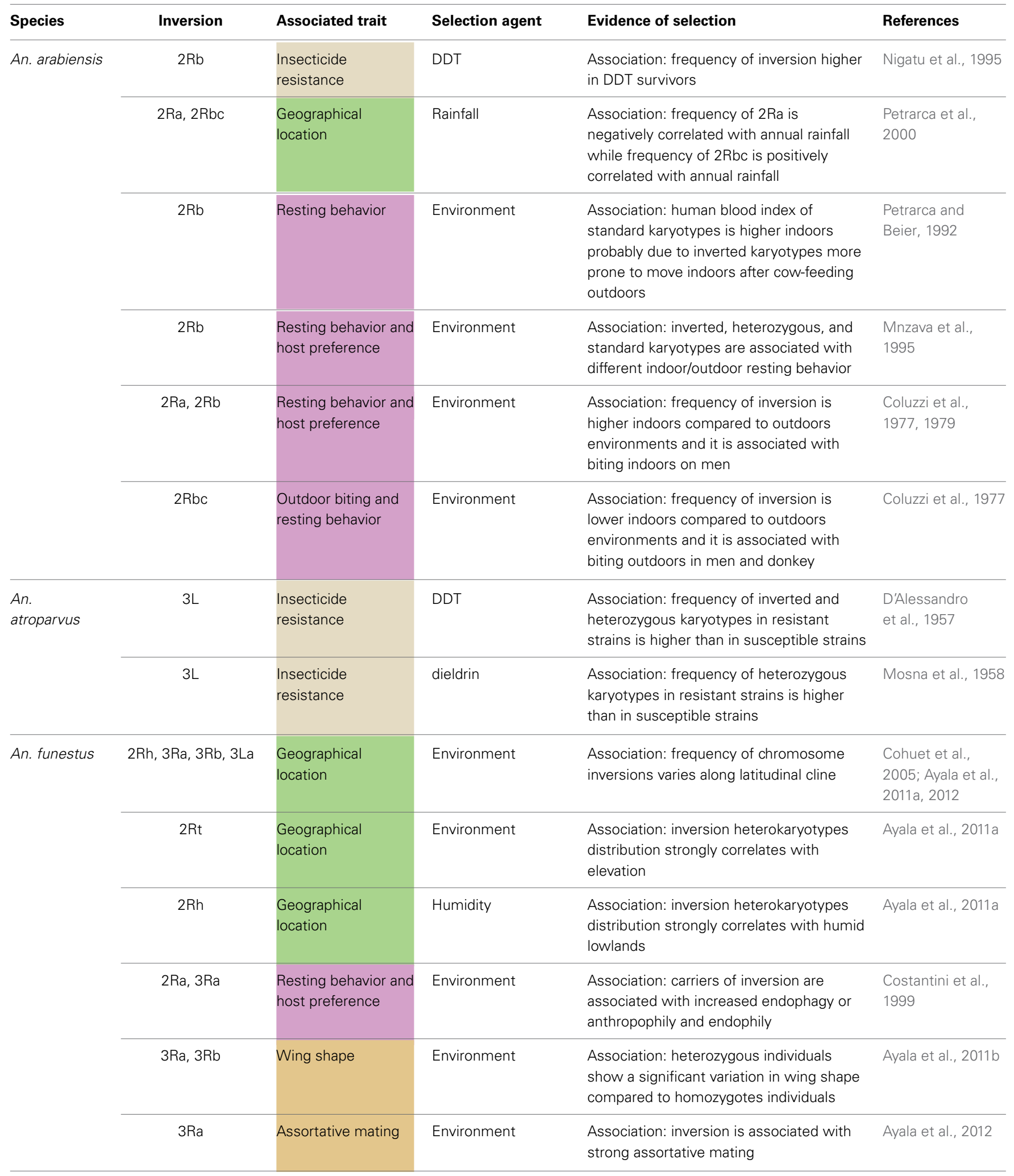


Table 1 | Continued

\begin{tabular}{|c|c|c|c|c|c|}
\hline Species & Inversion & Associated trait & Selection agent & Evidence of selection & References \\
\hline & $2 \mathrm{Ra}$ & $\begin{array}{l}\text { Infectivity to } \\
\text { Plasmodium }\end{array}$ & Parasite & $\begin{array}{l}\text { Association: carriers of inversion are more } \\
\text { likely to be infectious for } P \text { falciparum as } \\
\text { compared to non-inverted } \\
\text { homokaryotypes }\end{array}$ & $\begin{array}{l}\text { Costantini et al., } \\
1999\end{array}$ \\
\hline \multirow[t]{13}{*}{ An. gambiae } & $2 \mathrm{Rb}$ & $\begin{array}{l}\text { Insecticide } \\
\text { resistance }\end{array}$ & DDT & $\begin{array}{l}\text { Association: inversion frequency increases } \\
\text { with length of exposure to DDT }\end{array}$ & $\begin{array}{l}\text { Brooke et al., } \\
2002\end{array}$ \\
\hline & 2La & $\begin{array}{l}\text { Insecticide } \\
\text { resistance }\end{array}$ & Dieldrin, fipronil & $\begin{array}{l}\text { Phenotypic assays: higher survival of } \\
\text { heterozygous individuals while the } \\
\text { majority of knocked down individuals were } \\
\text { homozygous for } 2 \mathrm{La}\end{array}$ & $\begin{array}{l}\text { Brooke et al., } \\
2000\end{array}$ \\
\hline & $2 \mathrm{La}, 2 \mathrm{Rb}, 2 \mathrm{Rc}$ & $\begin{array}{l}\text { Geographical } \\
\text { location }\end{array}$ & Latitude & $\begin{array}{l}\text { Association: frequency of inversions } \\
\text { correlates with geographical locations }\end{array}$ & $\begin{array}{l}\text { Coluzzi et al., } \\
\text { 1985; Simard } \\
\text { et al., } 2009\end{array}$ \\
\hline & $2 \mathrm{La}$ & $\begin{array}{l}\text { Geographical } \\
\text { location }\end{array}$ & Arid climate & $\begin{array}{l}\text { Population re-sequencing: identification of } \\
\text { candidate genes responsible for the match } \\
\text { between inversion frequency and } \\
\text { environmental variables }\end{array}$ & Cheng et al., 2012 \\
\hline & $2 \mathrm{Rb}$ & $\begin{array}{l}\text { Geographical } \\
\text { location }\end{array}$ & Arid climate & $\begin{array}{l}\text { Population re-sequencing: } \\
\text { Immunoglobulin-like fold genes show the } \\
\text { highest level of differentiation in flies } \\
\text { collected at opposite ends of the cline }\end{array}$ & Cheng et al., 2012 \\
\hline & $2 \mathrm{La}, 2 \mathrm{Ru}$ & $\begin{array}{l}\text { Geographical } \\
\text { location }\end{array}$ & Arid climate & $\begin{array}{l}\text { Comparative genome hybridization: loci } \\
\text { within the inverted region are more } \\
\text { divergent compared to loci in collinear } \\
\text { regions }\end{array}$ & $\begin{array}{l}\text { White et al., 2007, } \\
2009\end{array}$ \\
\hline & $2 \mathrm{Rbc}$ & $\begin{array}{l}\text { Geographical } \\
\text { location }\end{array}$ & Dry environments & $\begin{array}{l}\text { Association: positive correlation between } \\
\text { inversion frequency and low vegetation } \\
\text { index value NDVI, typical from dry } \\
\text { environments }\end{array}$ & $\begin{array}{l}\text { Thompson et al., } \\
1997\end{array}$ \\
\hline & $2 \mathrm{Rbc}$ & $\begin{array}{l}\text { Geographical } \\
\text { location and } \\
\text { seasonal patterns }\end{array}$ & Rainfall/ environment & $\begin{array}{l}\text { Association: negative correlation between } \\
\text { the inversion frequency and rainfall, } \\
\text { frequency of inversion is higher in dry } \\
\text { season }\end{array}$ & Touré et al., 1994 \\
\hline & 2Rbc, 2Rd, 2La & $\begin{array}{l}\text { Geographical } \\
\text { location and } \\
\text { seasonal patterns }\end{array}$ & Environment & $\begin{array}{l}\text { Association: frequency of inversion is } \\
\text { higher in dry environments and in dry } \\
\text { season }\end{array}$ & $\begin{array}{l}\text { Rishikesh et al., } \\
1985\end{array}$ \\
\hline & $2 \mathrm{La}$ & $\begin{array}{l}\text { Larval } \\
\text { thermotolerance }\end{array}$ & Heat & $\begin{array}{l}\text { Phenotypic assays: 4th instar larvaes with } \\
\text { the inversion show increased } \\
\text { thermo-tolerance following heat hardening }\end{array}$ & Rocca et al., 2009 \\
\hline & 2La & $\begin{array}{l}\text { Larval } \\
\text { thermotolerance }\end{array}$ & Heat & $\begin{array}{l}\text { Gene expression: more heat responsive } \\
\text { and up-regulated genes in individuals with } \\
\text { the inversion, down-regulated genes in } \\
\text { individuals without the inversion }\end{array}$ & $\begin{array}{l}\text { Cassone et al., } \\
2011\end{array}$ \\
\hline & $2 \mathrm{Rb}$ & $\begin{array}{l}\text { Desiccation } \\
\text { resistance }\end{array}$ & Arid climate & $\begin{array}{l}\text { Phenotypic assays: modest effect of } 2 \mathrm{Rb} \\
\text { inversion in desiccation resistance }\end{array}$ & Fouet et al., 2012 \\
\hline & $2 \mathrm{La}$ & $\begin{array}{l}\text { Desiccation } \\
\text { resistance }\end{array}$ & Arid climate & $\begin{array}{l}\text { Phenotypic assays: inversion carriers } \\
\text { show higher survival under desiccation } \\
\text { stress due to lower water loss in } \\
\text { emerging females }\end{array}$ & $\begin{array}{l}\text { Gray et al., 2009; } \\
\text { Fouet et al., } 2012\end{array}$ \\
\hline
\end{tabular}


Table 1 | Continued

\begin{tabular}{|c|c|c|c|c|c|}
\hline Species & Inversion & Associated trait & Selection agent & Evidence of selection & References \\
\hline & $2 \mathrm{La}, 2 \mathrm{Rs}$ & $\begin{array}{l}\text { Desiccation } \\
\text { resistance }\end{array}$ & Arid climate & $\begin{array}{l}\text { Gene expression: responsive genes are } \\
\text { not over-represented in inversions }\end{array}$ & Wang et al., 2011 \\
\hline & 2Rd, 2La & $\begin{array}{l}\text { Indoor/outdoor } \\
\text { behavior }\end{array}$ & Environment & $\begin{array}{l}\text { Association: frequency of inversions is } \\
\text { higher indoors compared to outdoors }\end{array}$ & Coluzzi et al., 1979 \\
\hline & $2 \mathrm{Rj}$ & $\begin{array}{l}\text { Choice of breeding } \\
\text { place }\end{array}$ & Environment & $\begin{array}{l}\text { Association: inversion frequency higher in } \\
\text { rock pools than in puddles/swamps }\end{array}$ & $\begin{array}{l}\text { Manoukis et al., } \\
2008\end{array}$ \\
\hline & $2 \mathrm{La}$ & $\begin{array}{l}\text { Choice of breeding } \\
\text { place }\end{array}$ & Environment & $\begin{array}{l}\text { Association: correlation of 2La presence } \\
\text { with water conditions: lower temperature, } \\
\text { conductivity and total dissolved solids }\end{array}$ & $\begin{array}{l}\text { Sanford et al., } \\
2013\end{array}$ \\
\hline & 2La & $\begin{array}{l}\text { Infectivity to } \\
\text { Plasmodium }\end{array}$ & Parasite & $\begin{array}{l}\text { Association: infection rates for the } \\
\text { standard homokaryotype were twice } \\
\text { higher than for } 2 \text { La homokaryotype }\end{array}$ & $\begin{array}{l}\text { Petrarca and } \\
\text { Beier, } 1992\end{array}$ \\
\hline An. melas & $2 \mathrm{Rn}$ & $\begin{array}{l}\text { Indoor/outdoor } \\
\text { resting behavior and } \\
\text { host preference }\end{array}$ & Environment & $\begin{array}{l}\text { Association: inversion frequency is higher } \\
\text { indoors compare to outdoors and in } \\
\text { animals compared to humans }\end{array}$ & Bryan et al., 1987 \\
\hline \multirow[t]{3}{*}{ An. messeae } & $\mathrm{XL}, 2 \mathrm{R} 00,3 \mathrm{R} 11,3 \mathrm{~L}$ & $\begin{array}{l}\text { Geographical } \\
\text { location }\end{array}$ & Environment & $\begin{array}{l}\text { Association: frequency of inversions } \\
\text { correlates with North/South locations }\end{array}$ & $\begin{array}{l}\text { Perevozkin et al., } \\
2012 a\end{array}$ \\
\hline & $\begin{array}{l}\text { XL1, 2R11, 3R01 } \\
\text { 3L1 }\end{array}$ & Acoustic signals & Female choice & $\begin{array}{l}\text { Association: different inversion } \\
\text { combinations are associated with distinct } \\
\text { acoustic signals in males }\end{array}$ & $\begin{array}{l}\text { Perevozkin et al., } \\
2012 b\end{array}$ \\
\hline & $\begin{array}{c}\mathrm{XL1}, \mathrm{XL2}, 2 \mathrm{R} 1,3 \mathrm{R} 1 \\
\text { 3L1 }\end{array}$ & $\begin{array}{l}\text { Succinate } \\
\text { dehydrogenase } \\
\text { activity }\end{array}$ & Environment & $\begin{array}{l}\text { Association: correlation between } \\
\text { combination of inversions and level of } \\
\text { enzymatic activity }\end{array}$ & $\begin{array}{l}\text { Perevozkin and } \\
\text { Kurovsky, } 2009\end{array}$ \\
\hline An. nili & $2 \mathrm{Rb}, 2 \mathrm{Rc}$ & $\begin{array}{l}\text { Geographical } \\
\text { location }\end{array}$ & Environment & $\begin{array}{l}\text { Association: frequency of inversions } \\
\text { correlates with geographical locations }\end{array}$ & $\begin{array}{l}\text { Sharakhova et al., } \\
2011\end{array}$ \\
\hline \multirow[t]{10}{*}{ An. stephensi } & $3 \mathrm{Rd}$ & $\begin{array}{l}\text { Insecticide } \\
\text { resistance }\end{array}$ & Carbofuran & $\begin{array}{l}\text { Association: presence of heterozygous } \\
\text { inversion in resistant strain }\end{array}$ & Shetty et al., 2013 \\
\hline & $2 \mathrm{Rb}$ & $\begin{array}{l}\text { Insecticide } \\
\text { resistance }\end{array}$ & Alphametrin & $\begin{array}{l}\text { Association: presence of heterozygous } \\
\text { inversion in resistant strain }\end{array}$ & Shetty et al., 2013 \\
\hline & 2Ri, 2Lh & $\begin{array}{l}\text { Insecticide } \\
\text { resistance }\end{array}$ & DDT & $\begin{array}{l}\text { Association: presence of heterozygous } \\
\text { inversion in resistant strain }\end{array}$ & Shetty et al., 2013 \\
\hline & $2 \mathrm{Rj}$ & $\begin{array}{l}\text { Insecticide } \\
\text { resistance }\end{array}$ & Chlorpyrifos & $\begin{array}{l}\text { Association: presence of heterozygous } \\
\text { inversion in resistant strain }\end{array}$ & Shetty et al., 2013 \\
\hline & $2 \mathrm{Rk}$ & $\begin{array}{l}\text { Insecticide } \\
\text { resistance }\end{array}$ & Cyfluthrin & $\begin{array}{l}\text { Association: presence of heterozygous } \\
\text { inversion in resistant strain }\end{array}$ & Shetty et al., 2013 \\
\hline & 2R1 & $\begin{array}{l}\text { Insecticide } \\
\text { resistance }\end{array}$ & Deltamethrin & $\begin{array}{l}\text { Association: presence of heterozygous } \\
\text { inversion in resistant strain }\end{array}$ & Shetty et al., 2013 \\
\hline & $2 \mathrm{Rm}, 3 \mathrm{Re}$ & $\begin{array}{l}\text { Insecticide } \\
\text { resistance }\end{array}$ & Bifenthrin & $\begin{array}{l}\text { Association: presence of heterozygous } \\
\text { inversion in resistant strain }\end{array}$ & Shetty et al., 2013 \\
\hline & $2 \mathrm{Rn}, 3 \mathrm{Rf}, 3 \mathrm{Rg}$ & $\begin{array}{l}\text { Insecticide } \\
\text { resistance }\end{array}$ & Propoxur & $\begin{array}{l}\text { Association: presence of heterozygous } \\
\text { inversion in resistant strain }\end{array}$ & Shetty et al., 2013 \\
\hline & 2Ro, 3Rh, 3Ri & $\begin{array}{l}\text { Insecticide } \\
\text { resistance }\end{array}$ & Temephos & $\begin{array}{l}\text { Association: presence of heterozygous } \\
\text { inversion in resistant strain }\end{array}$ & Shetty et al., 2013 \\
\hline & 3La & $\begin{array}{l}\text { Insecticide } \\
\text { resistance }\end{array}$ & Neem oil & $\begin{array}{l}\text { Association: presence of heterozygous } \\
\text { inversion in resistant strain }\end{array}$ & Shetty et al., 2013 \\
\hline
\end{tabular}


Table 1 | Continued

\begin{tabular}{|c|c|c|c|c|c|}
\hline Species & Inversion & Associated trait & Selection agent & Evidence of selection & References \\
\hline & $2 \mathrm{Rkr}$ & $\begin{array}{l}\text { Daily distribution of } \\
\text { emergence }\end{array}$ & Circadian cycle & $\begin{array}{l}\text { Association: inverted, heterozygous, and } \\
\text { standard karyotypes are associated with } \\
\text { different emergence times }\end{array}$ & Coluzzi, 1972 \\
\hline & $2 \mathrm{Rb}$ & $\begin{array}{l}\text { Circadian flight } \\
\text { activity }\end{array}$ & Circadian cycle & $\begin{array}{l}\text { Association: inverted and standard } \\
\text { karyotypes are associated with different } \\
\text { lengths of the activity period }\end{array}$ & Jones, 1974 \\
\hline
\end{tabular}

\section{OTHER ASSOCIATED TRAITS}

Evidence for associations between inversions and traits such as infectivity by Plasmodium, acoustic signals, breeding place, circadian cycle, and morphometric variation have also been reported.

Directly linked to malaria transmission, infectivity by $P$. falciparum has been associated with inversions in An. funestus and An. gambiae (Petrarca and Beier, 1992; Costantini et al., 1999). A cluster of resistance genes has been located within inversion $2 \mathrm{La}$ in $\mathrm{An}$. gambiae (Riehle et al., 2006). Although still controversial, several studies have revealed Plasmodium infection to incur a fitness cost to Anopheles, mainly in reduced fecundity and/or survival (Hurd et al., 2005).

In An. messeae, changes in acoustic signals have been observed across different inversion carriers (Figure 1, Table 1; Perevozkin et al., 2012b). Selection for this trait may modify mosquitoes' mating systems: changes in the reception of acoustic signals can prevent mating, leading to reduced gene flow between populations (Pennetier et al., 2010).

Other biological processes affecting mating in anophelines have also been described. In An. stephensi, the circadian cycle has been related to one specific inversion (Table 1) (Coluzzi, 1972; Jones, 1974). Mating behavior is directly driven by the internal circadian rhythms of Anopheles (Sawadogo et al., 2013a), which may easily be selected to prevent gene flow, for instance. Moreover, the circadian cycle affects biting behavior, and, therefore, potentially survival and dispersion (Rund et al., 2013).

Similarly, breeding place selection has been shown to be a trait directly linked to the inversion 2Rj in An. gambiae (Manoukis et al., 2008). Choice of breeding place has a direct impact on many critical aspects of the biology of mosquitoes, for instance, larva competition and density, which bring about a reduction in emergences, and hence in survival (Muriu et al., 2013). Moreover, the availability of suitable breeding sites determines the distribution of mosquito species (Mouchet et al., 2008).

Finally, morphometric variation has been associated with inversions in An. funestus and An. gambiae (Ayala et al., 2011b; Fouet et al., 2012). Body size has been found to be a significant factor in several biological characteristics in mosquitoes: host seeking, malaria transmission, mating, and fecundity (Takken et al., 1998; Russell et al., 2011; Yaro et al., 2012; Sawadogo et al., 2013b), which represent evolutionary selection targets under particular environmental conditions.

Taken together, these associations demonstrate the high diversity and complexity of traits associated with chromosomal inversions in Anopheles species. Classical studies, such as those we have just described, are a first necessary step toward understanding chromosomal inversions in adaptation. However, studies aimed at identifying the specific genes responsible for these associations are also needed in order to fully understand the role of chromosomal inversions in adaptation.

\section{GENOMIC AND TRANSCRIPTOMIC APPROACHES TO THE STUDY OF INVERSIONS}

Recently, the broad availability of genomic and transcriptomic techniques has allowed chromosomal inversions to be studied at an unprecedented level of detail. Although scarce, a few studies have been carried out aimed at identifying the candidate genes responsible for environmental adaptation in An. gambiae. A first step toward this goal was the use of comparative genome hybridization techniques to map divergent regions between chromosomal inversions (White et al., 2007, 2009). These studies have resulted in the discovery of two relatively small regions likely responsible for the maintenance of inversion $2 \mathrm{La}$, and one region likely responsible for inversion $2 \mathrm{Ru}$, while no divergent regions could be identified for the other chromosome 2 inversions. Follow-up analysis, using a population re-sequencing approach, resulted in identification of the candidate genes inside the $2 \mathrm{La}$ and $2 R u$ diverged regions (Cheng et al., 2012). Interestingly, some of the biological functions associated with environmental adaption in An. gambiae-such as gustatory receptors, ion-channel related genes and regulation of chromatin and transcription-are shared with D. melanogaster (Kolaczkowski et al., 2011). These results suggest that that there might be parallel adaptive responses to similar selective environmental pressures in different species, e.g., in adaptation to arid environments.

Thermal and desiccation stresses are common threats to insects living in arid environments. In an attempt to identify the specific genes involved in responses to these two stresses, microarrays were used to compare the genome-wide expression of genes before and after these stress conditions (Cassone et al., 2011; Wang et al., 2011). Cassone et al. (2011) found that a large number of genes were heat responsive and up-regulated in larvae carrying the $2 \mathrm{La}$ inversion compared with larvae carrying the standard karyotype. Proteolytic, chaperone, and metabolic functions were over-represented in these genes (Cassone et al., 2011). On the other hand, Wang et al. (2011) did not find significant enrichment for genes involved in the response to desiccation in chromosomal inversions in An. gambiae mosquitos subject to acute desiccation stress. Given that both studies induced similar physiological stresses, we would expect both of them to identify candidate genes in the inverted regions. However, there were differences in the experimental conditions and in the mosquito 
developmental stages analyzed, which could explain, at least in part, the different results obtained in the two studies.

Capitalizing on the complete genome sequences and highthroughput molecular technologies already available, further studies should be devoted to understanding the genetic basis of Anopheles adaptation to local environmental conditions. To this end, inversions are compelling target genomic regions. Expression and genomic analyses should be linked to phenotypic assays to confirm the functional implications of the candidate genes identified. Eventually, all these analyses should pave the way to developing molecular assays to monitor the presence of inversions in the context of seasonal/environmental changes, which in turn will help in the design of more effective vector control strategies.

\section{CONCLUDING REMARKS}

The role of inversions in Anopheles adaptation has been the subject of study since the 1950s. Taken together, these studies reveal a variety of traits likely to be involved in adaptation. The classical explanation, proposed by Dobzhansky, is that inversions influence fitness by favoring the selection of co-adaptive alleles by reducing recombination (Dobzhansky, 1970). More recently, it has been shown that inversions containing locally adapted genes can spread in populations without the necessity of drift or coadaptation (Kirkpatrick and Barton, 2006). Alternatively, the genes flanking breakpoint regions may be altered when inversions occur ("position effects"; Sperlich, 1966), thus creating new structures (Mitelman et al., 2007) or modifying expression attributes (PérezOrtín et al., 2002; Puig et al., 2004), which may occasionally be selected and lead to adaptation. However, knowledge of the genes within inversions or affected by inversion breakpoints is still very limited. To date, the breakpoints of only three inversions in An. gambiae-2Rb (Lobo et al., 2010), 2Rj (Coulibaly et al., 2007), and 2La (Sharakhov et al., 2006) - and one in A. arabiensis-2Rd1 (Mathiopoulos et al., 1998)—have been characterized. The increasing availability of genomics and transcriptomics data from Anopheles will certainly accelerate identification of inversion genes likely playing a role in adaptation (Neafsey et al., 2013). Once identified, direct manipulation of these candidate genes to test the effects of specific alleles on a particular trait and in the same genetic background would provide direct evidence for their causal effect. Because of the limitations in carrying out experiments with Anopheles species in the laboratory, D. melanogaster may be used as a model to assess the effects of some of these candidate genes, as has already been done with insecticide resistance genes (Daborn et al., 2012). In addition, the availability of whole genome sequences will facilitate analysis of other types of genomic variants that may also be affecting the ability of Anopheles to adapt to different environments (Casacuberta and González, 2013; Neafsey et al., 2013).

\section{AUTHOR CONTRIBUTIONS}

Diego Ayala, Anna Ullastres and Josefa González contributed to the drafting and writing of this review.

\section{ACKNOWLEDGMENTS}

Anna Ullastres is an FPI fellow (BES-2012-052999) and Josefa González is a Ramón y Cajal fellow (RYC-2010-07306). This work was supported with startup funds from IRD-MIVEGEC awarded to Diego Ayala, and with grants from the European Commission (Marie Curie CIG PCIG-GA-2011-293860) and the Spanish Government (Fundamental Research Projects Grant BFU-2011-24397) awarded to Josefa González.

\section{REFERENCES}

Ayala, D., Caro-Riaño, H., Dujardin, J.-P., Rahola, N., Simard, F., and Fontenille, D. (2011b). Chromosomal and environmental determinants of morphometric variation in natural populations of the malaria vector Anopheles funestus in Cameroon. Infect. Genet. Evol. 11, 940-947. doi: 10.1016/j.meegid.2011.03.003

Ayala, D., Fontaine, M. C., Cohuet, A., Fontenille, D., Vitalis, R., and Simard, F. (2011a). Chromosomal inversions, natural selection and adaptation in the malaria vector Anopheles funestus. Mol. Biol. Evol. 28, 745-758. doi: $10.1093 / \mathrm{molbev} / \mathrm{msq} 248$

Ayala, D., Guerrero, R. F., and Kirkpatrick, M. (2012). Reproductive isolation and local adaptation quantified for a chromosome inversion in a malaria mosquito. Evolution 67, 946-958. doi: 10.1111/j.1558-5646.2012.01836.x

Ayala, F. J., and Coluzzi, M. (2005). Chromosome speciation: humans, Drosophila and mosquitoes. Proc. Natl. Acad. Sci. U.S.A. 102(Suppl. 1), 6535-6542. doi: 10.1073/pnas.0501847102

Bayoh, M. N., Thomas, C. J., and Lindsay, S. W. (2001). Mapping distributions of chromosomal forms of Anopheles gambiae in West Africa using climate data. Med. Vet. Entomol. 15, 267-274. doi: 10.1046/j.0269-283x.2001.00298.x

Besansky, N. J., Krzywinski, J., Lehmann, T., Simard, F., Kern, M., Mukabayire, O., et al. (2003). Semipermeable species boundaries between Anopheles gambiae and Anopheles arabiensis: evidence from multilocus DNA sequence variation. Proc. Natl. Acad. Sci. U.S.A. 100, 10818-10823. doi: 10.1073/pnas. 1434337100

Brooke, B. D., Hunt, R. H., Chandre, F., Carnevale, P., and Coetzee, M. (2002). Stable chromosomal inversion polymorphisms and insecticide resistance in the malaria vector mosquito Anopheles gambiae (Diptera: Culicidae). J. Med. Entomol. 39, 568-573. doi: 10.1603/0022-2585-39.4.568

Brooke, B. D., Hunt, R. H., and Coetzee, M. (2000). Resistance to dieldrin + fipronil assorts with chromosome inversion 2La in the malaria vector Anopheles gambiae. Med. Vet. Entomol. 14, 190-194. doi: 10.1046/j.1365-2915.2000.00222.x

Bryan, J. H., Petrarca, V., di Deco, M. A., and Coluzzi, M. (1987). Adult behaviour of members of the Anopheles gambiae complex in the Gambia with special reference to An. melas and its chromosomal variants. Parassitologia 29, 221-249.

Calvete, O., González, J., Betrán, E., and Ruiz, A. (2012). Segmental duplication, microinversion, and gene loss associated with a complex inversion breakpoint region in Drosophila. Mol. Biol. Evol. 29, 1875-1889. doi: 10.1093/molbev/mss067

Casacuberta, E., and González, J. (2013). The impact of transposable elements in environmental adaptation. Mol. Ecol. 22, 1503-1517. doi: 10.1111/mec.12170

Cassone, B. J., Molloy, M. J., Cheng, C., Tan, J. C., Hahn, M. W., and Besansky, N. J. (2011). Divergent transcriptional response to thermal stress by Anopheles gambiae larvae carrying alternative arrangements of inversion 2La. Mol. Ecol. 20, 2567-2580. doi: 10.1111/j.1365-294X.2011.05114.x

Cheng, C., White, B. J., Kamdem, C., Mockaitis, K., Costantini, C., Hahn, M. W., et al. (2012). Ecological genomics of Anopheles gambiae along a latitudinal cline: a population-resequencing approach. Genetics 190, 1417-1432. doi: 10.1534/genetics.111.137794

Cohuet, A., Dia, I., Simard, F., Raymond, M., Rousset, F., Antonio-Nkondjio, C., et al. (2005). Gene flow between chromosomal forms of the malaria vector Anopheles funestus in Cameroon, Central Africa, and its relevance in malaria fighting. Genetics 169, 301-311. doi: 10.1534/genetics.103.025031

Coluzzi, M. (1972). Inversion polymorphism and adult emergence in Anopheles stephensi. Science 176, 59-60. doi: 10.1126/science.176.4030.59

Coluzzi, M. (1982). Spatial distribution of chromosomal inversions and speciation in Anopheline mosquitoes. Prog. Clin. Biol. Res. 96, 143-153.

Coluzzi, M., Petrarca, V., and Di Deco, M. A. (1985). Chromosomal inversion intergradation and incipient speciation in Anopheles gambiae. Boll. Zool. 52, 45-63. doi: 10.1080/11250008509440343

Coluzzi, M., Sabatini, A., della Torre, A., di Deco, M. A., and Petrarca, V. (2002). A polytene chromosome analysis of the Anopheles gambiae species complex. Science 298, 1415-1418. doi: 10.1126/science.1077769

Coluzzi, M., Sabatini, A., Petrarca, V., and di Deco, M. A. (1977). Behavioural divergences between mosquitoes with different inversion karyotypes in polymorphic 
populations of the Anopheles gambiae complex. Nature 266, 832-833. doi: $10.1038 / 266832 \mathrm{a} 0$

Coluzzi, M., Sabatini, A., Petrarca, V., and di Deco, M. A. (1979). Chromosomal differentiation and adaptation to human environments in the Anopheles gambiae complex. Trans. R. Soc. Trop. Med. Hyg. 73, 483-497. doi: 10.1016/00359203(79)90036-1

Costantini, C., Sagnon, N., Ilboudo-Sanogo, E., Coluzzi, M., and Boccolini, D. (1999). Chromosomal and bionomic heterogeneities suggest incipient speciation in Anopheles funestus from Burkina Faso. Parassitologia 41, 595-611.

Coulibaly, M. B., Lobo, N. F., Fitzpatrick, M. C., Kern, M., Grushko, O., Thaner, D. V., et al. (2007). Segmental Duplication Implicated in the Genesis of Inversion 2Rj of Anopheles gambiae. PLOS ONE 2:e849. doi: 10.1371/journal.pone.00 00849

Daborn, P. J., Lumb, C., Harrop, T. W. R., Blasetti, A., Pasricha, S., Morin, S., et al. (2012). Using Drosophila melanogaster to validate metabolism-based insecticide resistance from insect pests. Insect. Biochem. Mol. Biol. 42, 918-924. doi: 10.1016/j.ibmb.2012.09.003

D’Alessandro, G., Lazzaro, G. F., and Mariani, M. (1957). Effect of DDT selection pressure on the frequency of chromosomal structures in Anopheles atroparvus. Bull. World Health Organ. 16, 859-864.

Della Torre, A. (1997). "Polytene chromosome preparation from anophheline mosquitoes," in Molecular Biology of Insect Disease Vectors: a Methods Manual, eds C. B. Beard, C. Louis, and J. M. Crampton (London: Chapman and Hall), 329-336. doi: 10.1007/978-94-009-1535-0_28

Della Torre, A., Merzagora, L., Powell, J. R., and Coluzzi, M. (1997). Selective introgression of paracentric inversions between two sibling species of the Anopheles gambiae complex. Genetics 146, 239-244.

Dobzhansky, T. (1937). Genetics and the Origin of Species. New York, NY: Columbia University Press.

Dobzhansky, T. (1970). Genetics of the Evolutionary Process. New York, NY: Columbia University Press.

Enayati, A., and Hemingway, J. (2010). Malaria management: past, present and future. Annu. Rev. Entomol. 55, 569-591. doi: 10.1146/annurev-ento-112408085423

Feder, J. L., Gejji, R., Powell, T. H. Q., and Nosil, P. (2011). Adaptive chromosomal divergence driven by mixed geographic mode of evolution. Evolution 65, 2157-2170. doi: 10.1111/j.1558-5646.2011.01321.x

Feder, J. L., and Nosil, P. (2009). Chromosomal inversions and species differences: when are genes affecting adaptive divergence and reproductive isolation expected to reside within inversions? Evolution 63, 3061-3075. doi: 10.1111/j.1558-5646.2009.00786.x

Feder, J. L., Roethele, J. B., Filchak, K., Niedbalski, J., and Romero-Severson, J. (2003). Evidence for inversion polymorphism related to sympatric host race formation in the apple maggot fly, Rhagoletis pomonella. Genetics 163, 939-953.

Fouet, C., Gray, E., Besansky, N. J., and Costantini, C. (2012). Adaptation to aridity in the malaria mosquito Anopheles gambiae: chromosomal inversion polymorphism and body size influence resistance to desiccation. PLoS ONE 7:e34841. doi: 10.1371/journal.pone.0034841

Gray, E. M., Rocca, K. A., Costantini, C., and Besansky, N. J. (2009). Inversion 2La is associated with enhanced desiccation resistance in Anopheles gambiae. Malar. J. 8:215. doi: 10.1186/1475-2875-8-215

Green, C. A., and Hunt, R. H. (1980). Interpretation of variation in ovarian polytene chromosomes of Anopheles Funestus Giles, A. Parensis Gillies, and A. Aruni? Genetica 51, 187-195. doi: 10.1007/BF00121610

Hoffmann, A. A., and Rieseberg, L. H. (2008). Revisiting the impact of inversions in evolution: from population genetic markers to drivers of adaptive shifts and speciation. Annu. Rev. Ecol. Evol. Syst. 39, 21-42. doi: 10.1146/annurev.ecolsys.39.110707.173532

Hoffmann, A. A., Sgrò, C. M., and Weeks, A. R. (2004). Chromosomal inversion polymorphisms and adaptation. Trends Ecol. Evol. 19, 482-488. doi: 10.1016/j.tree.2004.06.013

Hurd, H., Taylor, P. J., Adams, D., Underhill, A., and Eggleston, P. (2005). Evaluating the costs of mosquito resistance to malaria parasites. Evolution 59, 2560-2572. doi: 10.1111/j.0014-3820.2005.tb00969.x

Jones, M. D. R. (1974). Inversion polymorphism and circadian flight activity in the mosquito Anopheles stephensi List. (Diptera, Culicidae). Bull. Entomol. Res. 64, 305-311. doi: 10.1017/S0007485300031199

Kirkpatrick, M., and Barton, N. (2006). Chromosome inversions, local adaptation and speciation. Genetics 173, 419-434. doi: 10.1534/genetics.105.047985
Kirkpatrick, M., and Kern, A. (2012). Where's the money? Inversions, genes, and the hunt for genomic targets of selection. Genetics 190, 1153-1155. doi: 10.1534/genetics.112.139899

Kolaczkowski, B., Kern, A. D., Holloway, A. K., and Begun, D. J. (2011). Genomic differentiation between temperate and tropical Australian populations of Drosophila melanogaster. Genetics 187, 245-260. doi: 10.1534/genetics.110.123059

Krimbas, C. B., and Powell, J. R. (1992). Drosophila Inversion Polymorphism. Boca Raton, FL: CRC Press.

Kulathinal, R. J., Stevison, L. S., and Noor, M. A. F. (2009). The genomics of speciation in Drosophila: diversity, divergence, and introgression estimated using low-coverage genome sequencing. PLoS Genetics, 5:e1000550. doi: 10.1371/journal.pgen.1000550

Labbé, P., Berticat, C., Berthomieu, A., Unal, S., Bernard, C., Weill, M., et al. (2007). Forty years of erratic insecticide resistance evolution in the mosquito Culex pipiens. PLoS Genetics 3:e205. doi: 10.1371/journal.pgen.0030205

Lenormand, T. (2002). Gene flow and the limits to natural selection. Trends Ecol. Evol. 17, 183-189. doi: 10.1016/S0169-5347(02)02497-7

Lobo, N. F., Sangaré, D. M., Regier, A. A., Reidenbach, K. R., Bretz, D. A., Sharakhova, M. V., et al. (2010). Breakpoint structure of the Anopheles gambiae 2Rb chromosomal inversion. Malar. J. 9:293. doi: 10.1186/1475-2875-9-293

Manoukis, N. C., Powell, J. R., Touré, M. B., Sacko, A., Edillo, F. E., Coulibaly, M. B., et al. (2008). A test of the chromosomal theory of ecotypic speciation in Anopheles gambiae. Proc. Natl. Acad. Sci. U.S.A. 105, 2940-2945. doi: 10.1073/pnas.0709806105

Mathiopoulos, K. D., della Torre, A., Predazzi, V., Petrarca, V., and Coluzzi, M. (1998). Cloning of inversion breakpoints in the Anopheles gambiae complex traces a transposable element at the inversion junction. Proc. Natl. Acad. Sci. U.S.A. 95:12444. doi: 10.1073/pnas.95.21.12444

Mitelman, F, Johansson, B., and Mertens, F. (2007). The impact of translocations and gene fusions on cancer causation. Nat. Rev. Cancer 7, 233-45. doi: $10.1038 /$ nrc2091

Mnzava, A. E. P., Rwegoshora, R. T, Wilkes, T. J., Tanner, M., and Curtis, C. F. (1995). Anopheles arabiensis and An. gambiae chromosomal inversion polymorphism, feeding and resting behavior in relation to insecticide house-spraying in Tanzania. Med. Vet. Entomol. 9, 316-324.

Mosna, E., Rivosecchi, L., and Ascher, K. R. (1958). Studies on insecticide-resistant anophelines. I. Chromosome arrangements in a dieldrin-selected strain of Anopheles atroparvus. Bull. World Health Organ. 19, 297-301.

Mouchet, J., Carnevale, P., and Manguin, S. (2008). Biodiversity of Malaria in the World. Paris: John Libbey Eurotext.

Muriu, S. M., Coulson, T., Mbogo, C. M., and Godfray, H. C. J. (2013). Larval density dependence in Anopheles gambiae s.s., the major African vector of malaria. J. Anim. Ecol. 82, 166-174. doi: 10.1111/1365-2656.12002

Neafsey, D. E., Christophides, G. K., Collins, F. H., Emrich, S. J., Fontaine, M. C., Gelbart, W., et al. (2013). The evolution of the Anopheles 16 genomes project. G3 (Bethesda) 3, 1191-1194. doi: 10.1534/g3.113. 006247

Nigatu, W., Curtis, C. F., and Lulu, M. (1995). Test for association of DDT resistance with inversion polymorphism in Anopheles arabiensis from Ethiopia. J. Am. Mosq. Control Assoc. 11(2 Pt 1), 238-240.

Pennetier, C., Warren, B., Dabiré, K. R., Russell, I. J., and Gibson, G. (2010). Singing on the wing as a mechanism for species recognition in the malarial mosquito Anopheles gambiae. Curr. Biol. 20, 131-136. doi: 10.1016/j.cub.2009. 11.040

Perevozkin, V. P., Gordeev, M. I., Moskaev, A. V., Ahmetova, N. M., and Bondarchuk, S. S. (2012a). Inversion polymorphism and ecological specialization of malaria mosquitoes (Diptera, Culicidae) in Karelia. Russ. J. Genet. 48 , 679-683. doi: 10.1134/S1022795412060105

Perevozkin, V. P., and Kurovsky, A. V. (2009). Genetic determination of succinate dehydrogenase activity in Anopheles messeae (Diptera, Culicidae) Larvae. Russ. J. Genet. 45, 1162-1165. doi: 10.1134/S1022795409100020

Perevozkin, V. P., Printseva, A. A., Maslennikov, P. V., and Bondarchuk, S. S. (2012b). Genetic aspects of sexual behavior in malaria mosquitoes on the basis of specific acoustic signals at mating. Russ. J. Genet. 48, 587-591. doi: 10.1134/S1022795412060099

Pérez-Ortín, J. E., Querol, A., Puig, S., and Barrio, E. (2002). Molecular characterization of a chromosomal rearrangement involved in the adaptive evolution of yeast strains. Genome Res. 12, 1533-1539. doi: 10.1101/gr.436602 
Petrarca, V., and Beier, J. C. (1992). Intraspecific chromosomal polymorphism in the Anopheles gambiae complex as a factor affecting malaria transmission in the Kisumu area of Kenya. Am. J. Trop. Med. Hyg. 46, 229-237.

Petrarca, V., Nugud, A. D., Ahmed, M. A., Haridi, A. M., di Deco, M. A., and Coluzzi, M. (2000). Cytogenetics of the Anopheles gambiae complex in Sudan, with special reference to An. arabiensis: relationships with East and West African populations. Med. Vet. Entomol. 14, 149-164. doi: 10.1046/j.13652915.2000.00231.x

Puig, M., Cáceres, M., and Ruiz, A. (2004). Silencing of a gene adjacent to the breakpoint of a widespread Drosophila inversion by a transposoninduced antisense RNA. Proc. Natl. Acad. Sci. U.S.A. 101, 9013-9018. doi: 10.1073/pnas.0403090101

Ramírez, C. C., and Dessen, E. M. (2000). Chromosomal evidence for sibling species of the malaria vector Anopheles cruzii. Genome 43, 143-151. doi: 10.1139/g99-103

Riehle, M. M., Markianos, K., Niaré, O., Xu, J., Li, J., Touré, A. M., et al. (2006). Natural malaria infection in Anopheles gambiae is regulated by a single genomic control region. Science 312, 577-579. doi: 10.1126/science.1124153

Rishikesh, N., di Deco, M. A., Petrarca, V., and Coluzzi, M. (1985). Seasonal variations in indoor resting Anopheles gambiae and Anopheles arabiensis in Kaduna, Nigera. Acta Trop. 42, 165-170.

Rocca, K. A., Gray, E. M., Costantini, C., and Besansky, N. J. (2009). 2La chromosomal inversion enhances thermal tolerance of Anopheles gambiae larvae. Malar. J. 8, 147. doi: 10.1186/1475-2875-8-147

Rund, S. S., Gentile, J. E., and Duffield, G. E. (2013). Extensive circadian and light regulation of the transcriptome in the malaria mosquito Anopheles gambiae. BMC Genomics 14:218. doi: 10.1186/1471-2164-14-218

Russell, T. L., Lwetoijera, D. W., Knols, B. G. J., Takken, W., Killeen, G. F., and Ferguson, H. M. (2011). Linking individual phenotype to density-dependent population growth: the influence of body size on the population dynamics of malaria vectors. Proc. Natl. Acad. Sci. U.S.A. 278, 3142-3151. doi: $10.1098 / \mathrm{rspb} .2011 .0153$

Sanford, M. R., Ramsay, S., Cornel, A. J., Marsden, C. D., Norris, L. C., Patchoke, S., et al. (2013). A preliminary investigation of the relationship between water quality and Anopheles gambiae larval habitats in western Cameroon. Malar. J. 12:225. doi: 10.1186/1475-2875-12-225

Sawadogo, S. P., Costantini, C., Pennetier, C., Diabaté, A., Gibson, G., and Dabiré, R. K. (2013a). Differences in timing of mating swarms in sympatric populations of Anopheles coluzzii and Anopheles gambiae s.s. (formerly An. gambiae M and $\mathrm{S}$ molecular forms) in Burkina Faso, West Africa. Parasit. Vectors 6, 275. doi: 10.1186/1756-3305-6-275

Sawadogo, S. P., Diabaté, A., Toé, H. K., Sanon, A., Lefevre, T., Baldet, T., et al. (2013b). Effects of age and size on Anopheles gambiae s.s. male mosquito mating success. J. Med. Entomol. 50, 285-293. doi: 10.1603/ME12041

Sharakhov, I. V., White, B. J., Sharakhova, M. V., Kayondo, J., Lobo, N. F., Santolamazza, F., et al. (2006). Breakpoint structure reveals the unique origin of an interspecific chromosomal inversion (2La) in the Anopheles gambiae complex. Proc. Natl. Acad. Sci. U.S.A. 103, 6258-6262. doi: 10.1073/pnas.0509683103

Sharakhova, M. V., Xia, A., Leman, S. C., and Sharakhov, I. V. (2011). Arm-specific dynamics of chromosome evolution in malaria mosquitoes. BMC Evol. Biol. 11:91. doi: 10.1186/1471-2148-11-91

Shetty, N. J., Hariprasad, T. P. N., Sanil, D., and Zin, T. (2013). Chromosomal inversions among insecticide-resistant strains of Anopheles stephensi Liston, a malaria mosquito. Parasitol. Res. 12, 3851-3857. doi: 10.1007/s00436-013-3575-0

Simard, F., Ayala, D., Kamdem, G. C., Pombi, M., Etouna, J., Ose, K., et al. (2009). Ecological niche partitioning between Anopheles gambiae molecular forms in Cameroon: the ecological side of speciation. BMC Ecol. 9:17. doi: 10.1186/14726785-9-17

Sinka, M. E., Bangs, M. J., Manguin, S., Coetzee, M., Mbogo, C. M., Hemingway, J., et al. (2010). The dominant Anopheles vectors of human malaria in Africa, Europe and the Middle East: occurrence data, distribution maps and bionomic précis. Parasit. Vectors 3:117. doi: 10.1186/1756-3305-3-117

Sperlich, D. (1966). Equilibria for inversions induced by $\mathrm{x}$-rays in isogenic strains of Drosophila pseudoobscura. Genetics 53, 835-842.

Stump, A. D., Pombi, M., Goeddel, L., Ribeiro, J. M. C., Wilder, J. A., della Torre, A., et al. (2007). Genetic exchange in 2La inversion heterokaryotypes of Anopheles gambiae. Insect. Mol. Biol. 16, 703-709. doi: 10.1111/j.1365-2583. 2007.00764.x

Sturtevant, A. H., and Dobzhansky, T. (1936). Inversions in the third chromosome of wild races of Drosophila pseudoobscura, and their use in the study of the history of the species. Proc. Natl. Acad. Sci. U.S.A. 22, 448-450. doi: 10.1073/pnas.22.7.448

Subbarao, S. K., Nanda, N., Chandrahas, R. K., and Sharma, V. P. (1993). Anopheles culicifacies complex: cytogenetic characterization of Rameshwaram island populations. J. Am. Mosq. Control Assoc. 9, 27-31.

Takken, W., Klowden, M. J., and Chambers, G. M. (1998). Effect of body size on host seeking and blood meal utilization in Anopheles gambiae sensu stricto (Diptera: Culicidae): the disadvantage of being small. J. Med. Entomol. 35, 639-645.

Thompson, R., Begtrup, K., Cuamba, N., Dgedge, M., Mendis, C., Gamage-Mendis, A., et al. (1997). The matola malaria project: a temporal and spatial study of malaria transmission and disease in a suburban àrea of Maputo Mozambique. Am. J. Trop. Med. Hyg. 57, 550-559.

Touré, Y. T., Petrarca, V., Traoré, S. F., Coulibaly, A., Maïga, H. M., Sankaré, O., et al. (1994). Ecological genetic studies in the chromosomal form Mopti of Anopheles gambiae s.str. in Mali, west Africa. Genetica 94, 213-223. doi: 10.1007/BF01443435

Tripet, F., Wright, J., Cornel, A., Fofana, A., McAbee, R., Meneses, C., et al. (2007). Longitudinal survey of knockdown resistance to pyrethroid (kdr) in Mali, West Africa, and evidence of its emergence in the Bamako form of Anopheles gambiae s.s. Am. J. Trop. Med. Hyg. 76, 81-87.

van Doorn, G. S., and Kirkpatrick, M. (2007). Turnover of sex chromosomes induced by sexual conflict. Nature 449, 909-912. doi: 10.1038/nature 06178

Wang, M.-H., Marinotti, O., Vardo-Zalik, A., Boparai, R., and Yan, G. (2011). Genome-wide transcriptional analysis of genes associated with acute desiccation stress in Anopheles gambiae. PLoS ONE 6:e26011. doi: 10.1371/journal.pone.0026011

White, B. J., Cheng, C., Sangaré, D., Lobo, N. F., Collins, F. H., and Besansky, N. J. (2009). The population genomics of trans-specific inversion polymorphisms in Anopheles gambiae. Genetics 183, 275-288. doi: 10.1534/genetics.109. 105817

White, B. J., Collins, F. H., and Besansky, N. J. (2011). Evolution of Anopheles gambiae in relation to humans and malaria. Annu. Rev. Ecol. Evol. Syst. 42, 111-132. doi: 10.1146/annurev-ecolsys-102710-145028

White, B. J., Hahn, M. W., Pombi, M., Cassone, B. J., Lobo, N. F., Simard, F., et al. (2007). Localization of candidate regions maintaining a common polymorphic inversion (2La) in Anopheles gambiae. PLoS Genetics 3:e217. doi: 10.1371/journal.pgen.0030217

WHO. (2012). World Malaria Report 2012. Geneva.

Xia, A., Sharakhova, M. V., and Sharakhov, I. V. (2008). Reconstructing ancestral autosomal arrangements in the Anopheles gambiae complex. J. Comput. Biol. 15, 965-980. doi: 10.1089/cmb.2008.0076

Yaro, A. S., Touré, A. M., Guindo, A., Coulibaly, M. B., Dao, A., Diallo, M., et al. (2012). Reproductive success in Anopheles arabiensis and the M and S molecular forms of Anopheles gambiae: do natural sporozoite infection and body size matter? Acta Trop. 122, 87-93. doi: 10.1016/j.actatropica.2011.12.005

Conflict of Interest Statement: The authors declare that the research was conducted in the absence of any commercial or financial relationships that could be construed as a potential conflict of interest.

Received: 15 January 2014; accepted: 22 April 2014; published online: 21 May 2014. Citation: Ayala D, Ullastres A and González J (2014) Adaptation through chromosomal inversions in Anopheles. Front. Genet. 5:129. doi: 10.3389/fgene.2014.00129 This article was submitted to Evolutionary and Population Genetics, a section of the journal Frontiers in Genetics.

Copyright (C) 2014 Ayala, Ullastres and González. This is an open-access article distributed under the terms of the Creative Commons Attribution License (CC BY). The use, distribution or reproduction in other forums is permitted, provided the original author(s) or licensor are credited and that the original publication in this journal is cited, in accordance with accepted academic practice. No use, distribution or reproduction is permitted which does not comply with these terms. 